\title{
Teaching Reading through PowToon: Practices and Students' Attitude
}

\author{
Entis Sutisna, Asih Wahyuni, Lungguh Halira Vonti* \\ Faculty of Teacher Training and Educational Sciences, Pakuan University, Bogor \\ *Corresponding email: lungguh@unpak.ac.id
}

Received: 09 March 2020

Accepted: 10 June 2020

Published: 30 November 2020

\begin{abstract}
Technology has been in active use for a long time particularly in higher educational. Technology has been in active use for a long time particularly in higher educational institutions. Mainly, technology provides various opportunities to enhance students' performance to language learning. This present paper discusses the implementation and integration a technology- engagement teaching strategy with the aid of PowToon by focusing on students' vocabulary mastery and their reading comprehension. This study presents the teaching practices that occur through such an activity by applying Powtoon as a multimodal learning tool to enhance students' vocabulary mastery and reading comprehension. In addition, in the second section of this paper, this paper presents the students' attitude toward the teaching of reading through Powtoon. This paper concludes with comments about both the extent of Powtoon as a multimodal learning tool and about the future of teaching reading comprehension through technology in a multimodal world.
\end{abstract}

Keywords: technology, language learning, PowToon.

Abstrak: Teknologi telah lama digunakan secara aktif terutama di lembaga pendidikan tinggi. Terutama, teknologi memberikan berbagai peluang untuk meningkatkan kinerja siswa dalam pembelajaran bahasa. Makalah ini membahas penerapan dan integrasi strategi pengajaran keterlibatan teknologi dengan bantuan PowToon dengan berfokus pada penguasaan kosakata siswa dan pemahaman bacaan mereka. Penelitian ini menyajikan praktik pengajaran yang terjadi melalui kegiatan tersebut dengan menerapkan Powtoon sebagai alat pembelajaran multimoda untuk meningkatkan penguasaan kosakata dan pemahaman bacaan siswa. Selain itu, pada bagian kedua makalah ini, makalah ini memaparkan sikap siswa terhadap pengajaran membaca melalui Powtoon. Makalah ini diakhiri dengan komentar tentang sejauh mana Powtoon sebagai alat pembelajaran multimodal dan tentang masa depan pengajaran pemahaman membaca melalui teknologi di dunia multimoda.

Kata kunci: teknologi, pembelajaran bahasa, PowToon.

\section{To cite this article:}

Sutisna, E., Wahyuni. A., \& Vonti, L., H. (2020). Teaching Reading through PowToon: Practices and Students'Attitude. Jurnal Pendidikan Progresif, 10(3), 534-540. doi: 10.23960/jpp.v10.i3.202015. 


\section{INTRODUCTION}

Day by day technology is growing rapidly. Furthermore, technology users spread all over the world from various circles and generations. The technology can be transformed into the language classroom. By the development of the internet and technology, many people and companies are making the application and software for free or paid in order to support the educators in teaching, especially in the language classroom (Buche, 2019; Mezhuyev, 2019; Li, Seering \& Wallace, 2018; Novak, 2010).

One of the applications that can support the teachers in teaching is PowToon. PowToon as known as a software that provides the animation video and also added the sound. Therefore, the internet is really needed in using PowToon because it is the online software. The free icon, sound, and animation of PowToon are interesting, but this software also serves a paid menu to get more interesting icons, animations, and sounds. The result of created animation video from PowToon can be directly uploaded it into YouTube, so it will easy for students to watch and downloaded from YouTube. Besides that, PowToon is easy to use.

Refers to the language classroom that can be improved by the PowToon software, English is one of the language classrooms that have an important role in the school or university because English is the global language that is used as the international communication. In learning English, writing becomes one of the most important skills to learn (Sutisna, Vonti, \& Tresnady, 2019; Santos et.al., 2019; Riosec, et.al., 2017). Therefore, students need to be mastered in writing especially in narrative text. A narrative text is a piece of writing that tells the story by imaginary or based on the real incident in the past. In terms of student's ability in the understanding narrative text, the role of teachers is really important. Every student has the possibility to become bored while in learning because the students would rather watch a quick interactive video with animation than learning by the classic method. That is why some teachers use PowToon as a solution for teaching narrative text in the class.

However, every student has different abilities in understanding and some of them are difficult to understand the narrative text. It depends on classrooms situation and in what way the teacher gives the explanation. In the other sides, every student has their own perspective and challenges in the learning process, especially in learning narrative text through PowToon.

\section{LITERATURE REVIEW}

\section{Teaching Reading}

Reading is possibly the most extensively and intensively studied skill by experts in the field of language teaching among the four language skills. The results of the studies conducted for many decades on the nature of reading is that language educators should choose among a wide variety of teaching methods and techniques for students who are learning to read in their second language (SL) or foreign language (FL) (Grabe \& Stoller, 2019; Epstein et.al., 2018; Singer \& Alexander, 2017).

There are two main reasons that cause the crucial of reading. First, reading is beneficial to the students' personal life. Second, it is beneficial to their language acquisition for reading improves students' writing abilities, spelling and vocabulary knowledge.

\section{Theories of Teaching Reading}

There are three main theories which explain the nature of learning to read. First, the traditional theory, or bottom-up processing, which focused on the printed form of a text. Second, the cognitive view or top-down processing which enhanced the role of students' background knowledge in addition to what appeared on the 
printed page. Third, the metacognitive view, which is based on the control and manipulation that a reader can have on the act of comprehending a text, and emphasizes the involvement of the reader's result of thinking about what he is doing while reading.

For the first theory, the main method associated with the bottom-up approach to reading is known as phonics. Phonics emphasizes on repetition and on drilling using the sounds that make-up words. In other words, textual comprehension involves adding the meanings of words to get the meanings of clauses. Information is received and processed beginning with the smallest sound units, and proceeded to letter blends, words, phrases, and sentences. This method requires the students to match letters with sounds in a defined sequence (Hedgcock, \& Ferris, 2018; Bourdeaud'hui, 2018; Rezvani, 2017). These lower level skills are associated to the visual stimulus and are consequently concerned with recognizing and recalling. Most of exercises in textbooks for reading course for EFL and ESL are influenced by this method. Thus, this affected to the students' knowledge and experience in reading teaching and learning process.

On the other hand, meaningful learning, occurs when new information is presented in a relevant context and is related to leaners' background knowledge so that it can be easily integrated into one's existing cognitive structure. This emphasis on meaning eventually informed the top-down approach to L2 learning. These new cognitive approaches brings revolution to the conception of the way students learn to read. In this sense, reading is a dialogue between the reader and the text which involves an active cognitive process in which the reader's background knowledge plays a key role in the creation of meaning (Lee, 2019; Nguyen, 2018; Taha, 2017; Ahmed, 2017).
In the last theory, the context of reading, meta-cognition involves thinking about what one is doing while reading. They also involve many activities along the process of reading, whose stages can be divided into three, i.e. before reading (pre reading activity), while reading (whilst reading activity), and after reading (post reading activity). In the pre reading activities, the readers are to identify the purpose of the reading, identify the form or type of the text. In the second stage (while reading), they think about the general character and features of the form or type of the text - such as trying to locate a topic sentence and follow supporting details toward a conclusion, project the author's purpose for writing the text, choose, scan, or read in detail, make continuous predictions about what will occur next based on information obtained earlier, prior knowledge, and conclusions obtained within the previous stages. Finally, in the last stage, they attempt to form a summary, conclude, or make an inference of what was read.

\section{PowToon}

Powtoon Software was founded in January 2012. The company released a beta version in August 2012 and has seen fast subscriber growth. In February 2013 Powtoon introduced a free account option allowing users to create animated videos that can be exported in Youtube. It is a web-based animation software that allows users to create animated presentations by manipulating pre-created objects, images, provides music and others. Moreover the writer thinks that the use of this media will help teacher to develop their students motivation to learn.

Powtoon is a web-based animation software that allows teachers to quickly and easily create animated presentations by manipulating pre-created objects, imported images or videos, provided music and user created voiceovers making the teaching- learning process more 
engaging and enjoyable for young learners. Powtoon as a tool whose operations in the form of slides which text, images, animation and incorportation of sounds and music. Aweb based tool that offers a wide array of media options, graphics, cartoons, and animated images to create animated presentations that flow smoothly and logically (Siregar \& Frisnoiry, 2019; їiêîẩí, 2018; Sarkar, Ford, \& Manzo, 2017)

The writer concludes that Powtoon is a tool in a form of web-based animation presentation which is used easily with added text, images, music, videos in order to make these online visual presentations are a fast and eye-catching way to deliver information to diverse audiences within a very short time period. The students are not only watching the video, they also can observe the materials presented indirectly. There are several advantages of the use of Powtoon audio visual media such as: (1) it is interactive; (2) it covers all aspects of senses; (3) it is practically used; (4) it is collaborative, (5) it can be used in big group of students; (6) it is more various; (7) it gives feedback; and (8) it can motivate students.

\section{METHODS}

The researcher choses a descriptive qualitative method to investigate and describe the teaching practices and the students' attitudes in teaching reading through PowToon software. The researcher reports the data detail in the description.

The researcher uses the descriptive method to describe students' perspective and challenges on the interactive animation video in teaching reading through PowToon software. This research is conducted in English Language Education Study Program of Faculty of Teacher Training and Educational Science of Pakuan University.

There are some steps that the researcher uses to collect information about the teaching practices and the students' attitude in teaching reading through PowToon Software. For the first step, the researcher observes the teaching reading process by using PowToon software. After that, the researcher gives an open-ended questionnaire in order to get information about students' attitudes and. For the last step, to complete the data the researcher interviews some students and records it.

This research is conducted in English Language Education Study Program of Faculty of Teacher Training and Educational Science in Pakuan University. In this research, the researcher uses purposive sampling to take the sample. The researcher choses 25 students in the first semester as a participant. They are chosen because they are learning reading through the animation video from PowToon software that is not applied in the other classes.

\section{RESULTS AND DISCUSSION Classroom Observation}

The first data was collected through classroom observation. The classroom observation was conducted based on two indicators. There were the teaching reading practices and students' attitudes on the interactive animation video in teaching reading through PowToon software as a digital media. Therefore, the researcher also used the observation checklist in order to aid the data. The observation checklist provided three indicators for the teaching process; pre activity, whilst activity and post activity, and for the students' attitudes, six statements were provided.

\section{The Practices of Teaching Reading by Using PowToon}

Based on the data for the teaching process, in pre activity, the lecturer conducted the apperception to the students by playing talking stick by giving the question about students' experience in reading a story. In this activity, the teacher also asked about the characters of the story, setting, and what the story about. After that, 
the teacher asked the students about what they would learn. Based on the question that was given by the teacher, the students realized that they would learn the narrative text as one of the topic in reading material.

In whilst activity, the teacher showed the example of narrative text through animation video from PowToon software and gave the students the example of narrative text. The teacher then asked the students to retell the story about. The next activity, the teachers started to lead students into the explanation of narrative text through animation video from PowToon software.

In the post activity, the students watched the explanation of narrative text from the animation video from PowToon software, the teacher gave more explanation about the narrative text and asked the students several questions about the language feature and generic structure of narrative text. Then, the students responded those questions and answered correctly.

\section{The Observation of the students' Attitude}

Based on the first statement of the observation checklist, it mentioned that learning through animation video from PowToon software stimulates students' interesting in learning reading. Dealing with the first statement of the observation checklist, the fact in the class showed that the students were interested in the animation video that provided the narrative text material. Moreover, students in the class also showed the gestures when they were focused on the video and seemed happy to watch the interactive animation video from PowToon software.

The second statement of the observation checklist mentioned that learning through animation video from PowToon software increased students' motivation in asking and answering in the learning process. Dealing with this statement, the fact in the class showed that students seemed not really active in answered the teacher's question, sometimes the teacher needs to point the students to answer the question, but some students also answered the question without getting pointed by the teacher. While in asking process, there was only one student who asked.

The third statement of the observation checklist mentioned that learning through animation video from PowToon software help students' understanding in learning reading. Dealing with the statement, students in the class seemed to understand the narrative text materials, it was based on students' answer in the class that explains the narrative text in reading class (Frisnoiry, Darari, \& Refisis, 2019).

\section{Questionnaire}

The questionnaire was chosen as the second instrument to get the data. The questionnaire that was used in this research was open-ended questionnaire. The questionnaire was constructed based on the indicators that related to the theories. There were 8 questions that related to the students' attitudes on the interactive animation video in learning reading through PowToon software that should be answered by the students as the participants.

According to the questionnaire data, it shows that students' attitudes mentioned that learning narrative text through PowToon software can help students in understanding the material, especially in understanding the narrative text. Learning through animation can improve students' comprehension because of the display of captions along with the animation. The motion in the animation video itself attracts students' attention.

\section{Interview}

For the last step in collecting the data, the researcher interviewed 9 students as the participants. There were 5 questions of the interview. All of the questions were related to the 
indicators. The indicators were about the students' attitudes on the use of PowToon in teaching reading process.

Based from the interview data analysis, it shows that learning reading through the animation video from PowToon software make the learning process more interesting, and it can help students' understanding to the material. Learning through animation can improve students' comprehension because of the display of captions along with the animation. Refers to the first indicator about students' perspective into the interactive animation video from PowToon software, students' perspective mentioned that they can understand the material, and the learning process become more interesting. Therefore, students also mentioned that the animation video from PowToon software can be applied as learning media.

\section{CONCLUSIONS}

Learning through the animation video from PowToon software make the learning process more interesting. It means that Powtoon Software Program Application can be used as the teaching media to teaching reading. It is suggested that teaching through the animation video from PowToon software can be the other optional as teaching media, it can make the teaching learning process can be more interesting rather than teaching with the classic method. However, it was said that the motion of animation in the video in desctruct the students'

Therefore, the teachers need to realize to the motion of animation from video that can distract students' focuses in understanding the materials, so to reduce the distraction from the motion of animation video, the teachers can limit the animation or maybe minimize the size of the animation from the video so the students can be more focus on the material.

\section{REFERENCES}

Epstein, J. L., Sanders, M. G., Sheldon, S. B., Simon, B. S., Salinas, K. C., Jansorn, N. R., ... \& Williams, K. J. (2018). School, family, and community partnerships: Your handbook for action. Corwin Press.

Grabe, W., \& Stoller, F. L. (2019). Teaching and researching reading. Routledge.

Hedgcock, J. S., \& Ferris, D. R. (2018). Teaching readers of English: Students, texts, and contexts. Routledge.

Li, Z., Seering, W., \& Wallace, D. (2018, March). Understanding value propositions and revenue models in open source hardware companies. In ICIE 2018 6th International Conference on Innovation and Entrepreneurship: ICIE 2018 (p. 214). Academic Conferences and publishing limited.

Mezhuyev, V., Al-Emran, M., Ismail, M. A., Benedicenti, L., \& Chandran, D. A. (2019). The acceptance of search-based software engineering techniques: An empirical evaluation using the technology acceptance model. IEEE Access, 7, 101073-101085.

Novak, J. D. (2010). Learning, creating, and using knowledge: Concept maps as facilitative tools in schools and corporations. Routledge.

Rioseco, M., Paukner-Nogués, F., \& RamírezMuñoz, B. (2017). Incorporating powtoon as a learning activity into a course on technological innovations as didactic resources for pedagogy programs.

Sarkar, N., Ford, W., \& Manzo, C. (2017). Engaging digital natives through social learning. Systemics, Cybernetics and Informatics, 15(2), 1-4.

Singer, L. M., \& Alexander, P. A. (2017). Reading on paper and digitally: What the 
540 | Jurnal Pendidikan Progresif, Vol. 10, No. 3, pp. 534-540, November 2020

past decades of empirical research reveal. Review of educational research, 87(6), 1007-1041.

Siregar, T. M., \& Frisnoiry, S. (2019). BlogBased Learning Innovation with Powtoon Application in Facing Industrial Revolution 4.0. Britain International of Linguistics Arts and Education (BIoLAE) Journal, 1(2), 291-295.

Sutisna, E., Vonti, L. H., \& Tresnady, S. A. (2019). The Use Of Powtoon Software Program In Teaching And Learning Process: The Students'perception And Challenges. Jhss (Journal Of Humanities And Social Studies), 3(2), 81-85. 